\title{
Implementasi Nilai-Nilai Kewarganegaraan Terhadap Pembelajaran Daring
}

\author{
Jessica Angeline De Eloisa Tobing ${ }^{1}$, Dinie Anggraeni Dewi ${ }^{2}$ \\ Program Studi Pendidikan Guru Sekolah Dasar Universitas Pendidikan Indonesia Kampus Cibiru Jl. Pendidikan No.15, \\ Cibiru Wetan, Cileunyi, Bandung, Indonesia \\ angelineloisa18@upi.edu
}

\begin{abstract}
This study aims to describe the fulfillment of children's rights to get educational services during the Covid-19 emergency, describe appropriate character education to shape children's potential, and describe the concept of good and appropriate learning known as online mode during the Covid-19 pandemic. This research was conducted qualitatively using data collection techniques through observation. To analyze the data, the analysis was applied in the form of an interactive model through data collection, reduction, presentation and drawing conclusions. To test its validity, it uses triangulation of sources and methods. The results of this study conclude that the importance of character education in developing children's potential to think and have a good heart, and to behave in accordance with Pancasila philosophy. This character education has three main functions. First, the function of forming and developing potential. Second, the function of repair and strengthening. And third, the filter function. Teachers as infrastructure are preparing learning strategies and learning content and providing learning management systems during the Covid-19 pandemic. The main role in developing children's potential is of course relying on parents and the home environment.
\end{abstract}

Keywords: Children's Rights, Education During Pandemic, Character Education, Pancasila Philosophy

\begin{abstract}
Abstrak
Penelitian ini bertujuan untuk mendeskripsikan pemenuhan hak anak untuk mendapatkan layanan pendidikan selama darurat covid-19, mendeskripsikan pendidikan karakter yang tepat untuk membentuk potensi anak, dan mendeskripsikan konsep pembelajaran yang baik dan tepat yang dikenal dengan istilah moda daring selama pandemi covid-19. Penelitian ini dilakukan secara kualitatif dengan menggunakan teknik pengumpulan data melalui observasi. Untuk menganalisis data menerapkan analisis berupa model interaktif melalui pengumpulan data, reduksi, penyajian dan penarikan kesimpulan. Untuk menguji keabsahannya menggunakan triangulasi sumber dan metode. Hasil penelitian ini menyimpulkan bahwa Pentingnya pendidikan karakter dalam mengembangkan potensi anak agar berpikiran dan berhati baik, dan berperilaku sesuai dengan falsafah Pancasila. Pendidikan karakter ini memiliki tiga fungsi utama. Pertama, fungsi pembentukan dan pengembangan potensi. Kedua, fungsi perbaikan dan penguatan. Dan ketiga, fungsi penyaring. Guru sebagai infrastruktur adalah menyiapkan strategi pembelajaran dan konten belajar dan menyediakan learning management system selama pandemi covid-19 ini. Peran utama untuk mengembangkan potensi anak ini tentu mengandalkan orangtua dan lingkungan rumah.
\end{abstract}

Kata kunci: Hak Anak, Pendidikan Selama Pandemi, Pendidikan Karakter, Falsafah Pancasila

Copyright (c) 2021 Jessica Angeline De Eloisa Tobing

Corresponding author: Jessica Angeline De Eloisa Tobing

Email Address: angelineloisa18@upi.edu (Jl. Pendidikan No.15, Cibiru Wetan, Cileunyi, Bandung, Indonesia)

Received 22 March 2020, Accepted 24 April 2020, Published 30 April 2021

\section{PENDAHULUAN}

Sesuai UU No. 20 tahun 2003 dijelaskan Pendidikan adalah usaha sadar dan terencana untuk mewujudkan suasana belajar dan proses pembelajaran agar peserta didik secara aktif mengembangkan potensi dirinya untuk memiliki kekuatan spiritual keagamaan, pengendalian diri, kepribadian, kecerdasan, akhlak mulia, serta keterampilan yang diperlukan dirinya, masyarakat, bangsa, dan Negara. Oleh karena itu keberhasilan suatu proses pembelajaran ditentukan oleh faktor guru, sarana-prasarana, lingkungan dan sudah tentu peserta didik itu sendiri, memiliki kemauan atau motivasi untuk dapat 
secara aktif mengembangkan potensi dirinya. Sehingga tujuan pendidikan dalam rangka mempersiapkan generasi yang unggul berdaya saing dan memiliki kepribadian atau karakter bangsa dapat secara optimal dicapai sesuai amanat undang-undang tersebut. Tujuan pendidikan adalah bagaimana membentuk generasi yang seutuhnya artinya memiliki kecerdasan intelektual, sikap yang baik dan dengan keterampilan yang diperlukan dalam menjalani hidup di masyarakat. Hal inilah yang menjadi tugas guru dalam melaksanakan proses pembelajaran sebagai bagian dari proses pendidikan untuk dapat menghasilkan pembelajaran yang outputnya adalah keseimbangan capaian kognitif, afektif atau sikap dan psikomotor. Oleh karena itu dalam proses pembelajaran kewajiban dan peran guru sangatlah vital, guru harus mampu sebagai fasilitator maupun mengidentifikasi segala keunggulan dan kelemahan model-model pembelajaran yang akan diterapkan sehingga benar-benar menciptakan suatu pembelajaran yang efektif, karena guru "mengajar pada dasarnya merupakan suatu usaha untuk menciptakan kondisi atau sistem lingkungan yang mendukung dan memungkinkan untuk berlangsungnya proses belajar" (Sardiman, 2011:47).

Pada masa pandemi Covid-19 ini Pemerintah mengeluarkan kebijakan tentang bagaimana pelaksanaan pembelajaran daring dan luring. Dalam Kamus Besar Bahasa Indonesia diartikan dalam jaringan, terhubung melalui jejaring komputer, internet, dan sebagainya. Pembelajaran daring dilaksanakan sebagai langkah tepat untuk dapat mencegah dan menekan penularan virus Covid-19, pun peserta didik tidak akan ketinggalan pelajaran sebagaimana yang telah direncanakan dalam kurikulum selama satu tahun ajaran. Walaupun pemerintah sudah mengeluarkan kebijakan New Normal yang tujuannya adalah menghidupkan kembali sektor perekonomian yang sudah kurang lebih 3 bulan lumpuh akibat dampak Covid-19, akan tetapi sektor pendidikan khususnya pembelajaran di sekolah belum sepenuhnya berani dibuka oleh pemerintah. Hal ini dikarenakan anak usia sekolah adalah anak yang cenderung masih labil dan senang akan berkumpul dengan teman-temannya sehingga memungkinkan terjadinya penyebaran virus tersebut. Oleh karena itu pembelajaran yang dilakukan saat ini bersifat during yang sifatnya jarak jauh.

Sudah tentunya menjadi tantangan tersendiri bagi guru dalam rangka capaian hasil belajar terutama dalam usaha pendidikan karakter anak. Pendidikan karakter merupakan penciptaan lingkungan sekolah yang membantu siswa dalam perkembangan etika, tanggung jawab melalui model, dan pengajaran karakter yang baik melalui nilai-nilai universal (Berkowitz \& Bier, 2005:7). Dengan pembelajaran yang dilakukan diluar lingkungan sekolah dalam hal ini menggunakan pembelajaran daring yang sifatnya jarak jauh, memberikan tugas dan tanggung jawab ekstra serta tantangan bagi guru untuk mampu menciptakan lingkungan pembelajaran dalam upaya perkembangan etika, tanggung jawab dan karakter peserta didik tersebut. Karena metode evaluasi dari pendidikan karakter salah satunya dengan observasi langsung oleh guru, yang mengamati sikap atau perubahan sikap baru yang muncul pada diri peserta didik. Belum lagi kendala yang dihadapi guru dalam penerapan pembelajaran daring misalnya penguasaan teknologi, kendala jaringan internet dan inovasi pengintegrasian 
Implementasi Nilai-Nilai Kewarganegaraan Terhadap Pembelajaran Daring, Jessica Angeline De Eloisa Tobing, Dinie Anggraeni Dewi

pendidikan karakter pada pembelajaran daring yang seolah baru booming ketika pandemi Covid-19 terjadi.

\section{METODE}

\section{Setting Penelitian}

Metode penelitian kajian pustaka atau studi kepustakaan yaitu berisi teori-teori yang relevan dengan masalah-masalah penelitian. Masalah pada penelitian ini adalah untuk mengetahui 'Implementasi nilai-nilai kewarganegaraan terhadap pembelajaran daring'. Pada bagian ini dilakukan pengkajian mengenai konsep dan teori yang digunakan berdasarkan literatur yang tersedia, terutama dari artikel-artikel yang dipublikasikan dalam berbagai jurnal ilmiah. Adapun jenis penelitian yang digunakan dalam penelitian ini adalah penelitian kepustakaan atau library research, yakni penelitian yang dilakukan melalui pengumpulan data atau telaah yang dilaksanakan untuk memecah suatu masalah yang tertumpu pada penelaahan kritis dan mendalam terhadap bahan-bahan pustaka yang relevan. Sebelum melakukan telaah bahan pustaka, peneliti harus mengetahui terlebih dahulu secara pasti tentang sumber informasi yang diperoleh

\section{Teknik Pengumpulan Data}

Metode pengumpulan data penelitian ini diambil dari sumber data. Sumber data dalam penelitian adalah subjek dari mana data dapat diperoleh. Setelah keseluruhan data terkumpul maka langkah selanjutnya adalah penulis menganalisa data tersebut sehingga mendapat suatu kesimpulan. Untuk memperoleh hasil yang benar dan tepat dalam menganalisa data, penulis menggunakan teknik analisis isi. Analisis isi (Content Analysis) adalah penelitian yang bersifat pembahasan mendalam terhadap isi suatu informasi tertulis atau tercetak di media massa.

\section{HASIL DAN DISKUSI}

\section{Pandemi Covid-19}

Pandemi Covid-19 ialah krisis kesehatan yang menggemparkan dunia pada awal tahun 2020. Dunia dikagetkan dengan merebaknya sebuah virus baru yaitu coronavirus jenis baru (SARS-Cov-2) dan penyakitnya disebut Coronavirus Disease (Covid-19). Virus jenis baru ini berasal dari Wuhan, Tiongkok yang ditemukan pada akhir Desember tahun 2019. Virus corona merupakan keluarga besar virus sumber penyakit ringan hingga berat, seperti pilek dan penyakit serius seperti SARS dan MERS. Infeksi Covid-19 dapat menimbulkan gejala sedang hingga berat. Gejala klinis yang timbul yaitu kesulitan bernafas, batuk, hingga demam. Selain itu dapat disertai dengan sesak nafas memberat, fatigue, myalgia, gejala gastrointestinal seperti diare serta gejala saluran nafas lain. Setengah dari beberapa pasien muncul sesak dalam satu minggu. Virus ini disebut sebagai pandemi karena merebak dengan cepat ke berbagai negara, salah satunya dengan dibawa oleh para wisatawan atau orang orang yang berkunjung ke negara lain yang tanpa sadar telah terpapar virus corona sehingga mereka menyebarkannya ke orang lain yang belum terpapar. Begitulah virus ini bermutasi di dunia. 
Salah satu negara yang terdampak akibat virus corona ini ialah Indonesia. Banyak sektor di Indonesia yang terkena dampaknya. Sektor pendidikan merupakan salah satu sektor yang merasakan dampak dari adanya pandemi ini. Banyak sekolah maupun perguruan tinggi ditutup guna mengurangi penyebaran virus ini. Hal tersebut membuat pemerintah maupun lembaga terkait memikirkan alternatif demi kelangsungan proses pembelajaran. Salah satunya ialah dengan keluarnya SE Mendikbud No.4 Tahun 2020 yang membahas mengenai pembelajaran jarak jauh. Menurut data dari UNESCO Perubahan proses pelaksanaan pembelajaran ini dianggap paling efektif di tengah pandemi ini. Perubahan pola pelaksanaan pembelajaran sampai saat ini masih dilakukan salah satunya di tingkat Sekolah Dasar. Hal ini tentunya menuntut instansi pendidikan dan pendidik yang bertanggung jawab untuk menerapkan proses pembelajaran yang tepat. Kebijakan yang dikeluarkan pemerintah yaitu Belajar Dari Rumah, bekerja dari rumah, dengan menerapkan physical distancing (jaga jarak) agar Covid-19 tidak semakin merebak diharuskan untuk belajar dengan pola pembelajaran jarak jauh. Pembelajaran jarak jauh memiliki karakteristik atau ciri khas yang berbeda dengan sistem pendidikan yang diselenggarakan secara tatap muka atau konvensional. Karakteristik tersebut ialah aktivitas fisik pengajar yang dipisahkan dengan pembelajar yang menjadikan keterbatasan proses pembelajaran dikarenakan tiada tatap muka secara langsung (Munir, 2012:8).

\section{Konsep Pembelajaran Daring}

Sesuai dengan ringkasan keputusan bersama 4 Menteri tahun 2020 diantaranya adalah Menteri Pendidikan dan Kebudayaan (Mendikbud) seperti yang dikatakan oleh Lanny Anggraini (2020) dalam Webinar Nasional PGSD Universitas Dwijendra salah satunya adalah prinsip kebijakan pendidikan di masa Covid-19: kesehatan dan keselamatan seluruh pihak prioritas utama dalam menetapkan kebijakan pembelajaran. Diantaranya meliputi, PAUD, Pendidikan Dasar dan Menengah, perguruan Tinggi, pesantren dan pendidikan Keagamaan. Dengan demikian pemerintah berupaya mengutamakan keselamatan semua pihak dalam proses pendidikan dalam menanggulangi dan mencegah Covid-19. Untuk itu diperlukan metode pembelajaran yang dapat mengakomodir hal tersebut sehingga proses pembelajaran dapat tetap berjalan dalam rangka mencerdaskan anak bangsa Berdasarkan KB 4 Menteri, Sekretaris Jenderal kementerian pendidikan dan kebudayaan mengeluarkan surat edaran no 15 tahun 2020 tentang pedoman penyelenggaraan belajar dari rumah dalam masa darurat penyebaran coronavirus disease (covid-19) yang tujuannya adalah memastikan pemenuhan hak anak untuk mendapatkan layanan pendidikan selama darurat Covid-19, dan mencegah serta melindungi warga satuan pendidikan dari dampak Covid-19 tersebut.

Konsep belajar dari rumah ini direalisasikan dengan istilah belajar moda daring yang memungkinkan tetap adanya interaksi antara guru dan siswa dalam proses pembelajaran. Pembelajaran daring menggunakan kemajuan teknologi informasi dan akses internet. Pembelajaran daring, atau dalam jaringan, adalah terjemahan dari istilah online yang bermakna tersambung ke dalam jaringan komputer. Dengan kata lain merupakan pembelajaran tanpa tatap muka secara langsung antara guru dan siswa, 
Implementasi Nilai-Nilai Kewarganegaraan Terhadap Pembelajaran Daring, Jessica Angeline De Eloisa Tobing, Dinie Anggraeni Dewi

tetapi dilakukan melalui jaringan internet (online) dari tempat yang berbeda-beda. Menurut Astra Winaya (2020) dalam Webinar Nasional PGSD Universitas Dwijendra, Pembelajaran dilakukan melalui video conference, e-learning atau distance learning. Lebih lanjut Ditjen Guru dan Tenaga Kependidikan Kementerian Pendidikan dan Kebudayaan dalam guru pembelajaran petunjuk teknis peningkatan program peningkatan kompetensi guru pembelajar moda dalam jaringan tahun 2016 menjelaskan Pendekatan pembelajaran pada Guru Pembelajar moda daring memiliki karakteristik sebagai berikut:

1. Menuntut pembelajar untuk membangun dan menciptakan pengetahuan secara mandiri (constructivism);

2. Pembelajar akan berkolaborasi dengan pembelajar lain dalam membangun pengetahuannya dan memecahkan masalah secara bersama-sama (social constructivism);

3. Membentuk suatu komunitas pembelajar (community of learners) yang inklusif;

4. Memanfaatkan media laman (website) yang bisa diakses melalui internet, pembelajaran berbasis komputer, kelas virtual, dan atau kelas digital;

5. Interaktivitas, kemandirian, aksesibilitas, dan pengayaan;

Kelebihan pembelajaran daring diantaranya adalah,

1. Pembelajaran tidak memerlukan ruang kelas, karena proses pembelajaran berlangsung dari rumah atau jarak jauh. Siswa di tempat atau lingkungan masing-masing yang dapat menciptakan suasana belajar dengan fasilitas internet yang ada.

2. Guru tidak perlu tatap muka secara langsung di depan kelas, karena yang digunakan adalah fasilitas komputer yang dihubungkan dengan internet.

3. Tidak terbatas waktu maksudnya adalah pembelajaran bisa dilakukan kapanpun, dimanapun sesuai dengan kesepakatan selama lingkungan dan fasilitas mendukung untuk terlaksananya proses pembelajaran moda daring tersebut.

Oleh karena itu mode pembelajaran daring ini bisa dikatakan lebih efisien dan efektif apabila suprastruktur dan infrastruktur tersedia dengan baik. Suprastruktur dapat diartikan penulis sebagai kebijakan yang mengarah pada pelaksanaan pembelajaran daring tersebut termasuk pemahaman dan kesiapan peserta didik dan guru dalam pelaksanaan pembelajaran daring. Kesiapan peserta didik diantaranya adalah 1 . Keterampilan menggunakan teknologi dan informasi dan komunikasi, hal ini menjadi poin dasar bagi peserta didik dalam pelaksanaan pembelajaran daring yang harus mampu menggunakan teknologi sehingga bisa maksimal dalam proses pembelajaran. 2. Kemandirian belajar tanpa harus diawasi oleh orang tua, 3. Sikap, yang diwujudkan dengan perilaku peserta didik dalam keseriusan mengikuti setiap tahap dalam proses pembelajaran daring. 4. Tanggung jawab adalah sikap dan perilaku melaksanakan tugas dengan sebaik-baiknya dalam pelaksanaan pembelajaran sesuai dengan arahan guru.

Peran guru dalam proses pembelajaran daring juga sangat vital, yang pertama menjadikan peserta didik sebagai aktivitas belajar karena guru harus menjadikan dasar pendekatan konstruktivistik 
yang menjadikan peserta didik sebagai subjek pembelajar. Kedua, menguasai TIK dan update akan informasi, ketiga, menciptakan suasana belajar yang interaktif, inspiratif dan menyenangkan, keempat, memberikan evaluasi dan umpan balik setelah proses pembelajaran berlangsung. Secara garis besar komponen yang harus dipersiapkan oleh guru sebagai infrastruktur adalah ketersediaan jaringan internet, menyiapkan strategi pembelajaran, menyiapkan konten belajar (efek, gambar, audio, video dan simulasi), menyediakan learning management system (google classroom, zoom, jitsi, webex, dll). Pada dasarnya keberhasilan proses pembelajaran daring memerlukan sinergitas antara pemerintah, satuan pendidikan, guru, peserta didik tentunya peran orang tua dan lingkungan peserta didik untuk dapat mendukung keberhasilan proses pembelajaran daring tersebut.

\section{Diskusi}

Pendidikan karakter memiliki tiga fungsi utama. Pertama, fungsi pembentukan dan pengembangan potensi. Pendidikan karakter membentuk dan mengembangkan potensi siswa agar berpikiran baik, berhati baik, dan berperilaku sesuai dengan falsafah Pancasila. Kedua, fungsi perbaikan dan penguatan. Pendidikan karakter memperbaiki dan memperkuat peran keluarga, satuan pendidikan, masyarakat, dan pemerintah untuk ikut berpartisipasi dan bertanggung jawab dalam pengembangan potensi warga negara dan pembangunan bangsa menuju bangsa yang maju, mandiri, dan sejahtera. Ketiga, fungsi penyaring. Pendidikan karakter memilah budaya bangsa sendiri dan menyaring budaya bangsa lain yang tidak sesuai dengan nilai-nilai budaya bangsa dan karakter bangsa yang bermartabat (Zubaidi, 2011:18). Dengan demikian pembentukan karakter bangsa ini harus melibatkan sinergitas ketiga komponen pendidikan antara lain pendidikan informal, formal dan non formal. Menghadapi tantangan zaman yang saat ini memasuki era revolusi industri 4.0 yang sarat akan kemajuan teknologi digitalisasi, penanaman dan penguatan karakter bangsa sangat vital dan mendesak. Berkembanganya nilai-nilai individualistis, hedonis, materialistis dan sebagainya merupakan dampak buruk dari arus globalisasi dan revolusi industri 4.0 tersebut. Apabila ini dibiarkan maka akan memberikan pengaruh buruk bagi kelangsungan kehidupan berbangsa yang tidak lagi mencerminkan nilai-nilai kepribadian bangsa.

Dijelaskan lebih lanjut ada empat alasan mendasar mengapa sistem pendidikan di Indonesia perlu menekankan pada pendidikan karakter, alasan tersebut yaitu: 1. Karena banyak keluarga (tradisional maupun non tradisional) yang tidak melaksanakan pendidikan karakter; 2. Karena peran sekolah tidak hanya bertujuan membentuk anak yang cerdas, tetapi juga anak yang baik; 3. Kecerdasan seorang anak hanya bermakna manakala dilandasi dengan kebaikan; 4. Karena membentuk anak didik agar berkarakter tangguh bukan hanya sekadar tugas tambahan bagi guru, melainkan tanggung jawab yang melekat pada perannya sebagai guru (Akin,1995:1). Dengan pendidikan karakter yang terintegrasi dalam proses pembelajaran ini menandakan pembelajaran yang bermakna yaitu kapabilitas yang berguna bagi kehidupan peserta baik untuk kepentingan belajar lebih lanjut maupun disumbangkan dalam pemecahan masalah di lingkungan masyarakat. 
Implementasi Nilai-Nilai Kewarganegaraan Terhadap Pembelajaran Daring, Jessica Angeline De Eloisa Tobing, Dinie Anggraeni Dewi

Kemendiknas (2011) telah mengidentifikasi delapan belas karakter yang harus mampu diimplementasikan oleh guru dalam proses pembelajaran diantaranya adalah: 1. Religius adalah sikap dan perilaku yang patuh dalam melaksanakan ajaran agama yang dianutnya, serta toleran terhadap agama lain, 2. Jujur adalah sikap yang dapat dipercaya dalam perkataan, tindakan 3. Toleransi adalah sikap dan tindakan yang menghargai perbedaan agama, suku, ras, pendapat, sikap, dan tindakan orang lain 4. Disiplin adalah tindakan yang menunjukan perilaku tertib dan patuh pada berbagai ketentuan dan peraturan yang berlaku, 5. Kerja keras adalah sikap dan perilaku yang pantang menyerah dalam upaya mencapai tujuan 6. kreatif adalah berpikir dan melakukan sesuatu untuk menghasilkan hal baru dari sesuatu yang telah dimiliki 7. Mandiri adalah sikap dan perilaku yang tidak mudah tergantung pada orang lain dalam menyelesaikan tugas-tugas yang diberikan 8, Demokratis adalah cara berpikir, bersikap, dan bertindak yang menilai sama hak dan kewajiban dirinya dan orang lain 9. rasa ingin tahu adalah sikap dan tindakan yang selalu berupaya untuk mengetahui lebih mendalam atau mengetahui hal-hal baru,10. semangat kebangsaan adalah cara berpikir, bertindak, dan berwawasan yang menempatkan kepentingan bangsa dan negara di atas kepentingan pribadi dan golongannya, 11.cinta tanah air adalah cara berpikir, bertindak, dan berwawasan kebangsaan selalu setia pada tanah airnya, 12. Menghargai prestasi adalah sikap dan tindakan yang berusaha menghasilkan prestasi atau mencapai kesuksesan dan menghargai keberhasilan orang lain, 13. Bersahabat/komunikatif adalah sikap dan tindakan yang terbuka dalam menjalin hubungan dan berkomunikasi dengan orang lain, 14. Cinta damai adalah sikap dan tindakan yang mengutamakan perdamaian dan ketentraman bersama, 15. Gemar membaca adalah kebiasaan menyediakan waktu untuk membaca atau menggali informasi melalui media bacaan untuk kepentingan dirinya dan orang banyak, 16 .

Peduli lingkungan adalah cara berpikir, bertindak, dan berwawasan yang menempatkan kepentingan bangsa dan negara di atas kepentingan diri dan kelompoknya, 17 peduli sosial adalah sikap dan tindakan ingin memberi bantuan pada orang lain dan masyarakat yang membutuhkan. Dan 18. Tanggung jawab adalah sikap dan perilaku untuk melaksanakan tugas dan kewajibannya dengan sebaikbaiknya. Dari delapan belas nilai karakter tersebut bisa pengembangannya sesuai dengan analisis konteks dan kebutuhan di masing-masing satuan pendidikan. Tentunya juga bagi guru dalam megengbangkan materi pembelajaran harus juga menganalisis materi pembelajaran yang disesuaikan dengan masing-masing nilai karakter tersebut. Tujuannya adalah antara materi pembelajaran dengan output yang dihasilkan sesuai dengan kebutuhan di masyarakat.

\section{UCAPAN TERIMA KASIH}

Ucapan terima kasih sangat layak disampaikan untuk semua pihak yang telah membantu dalam pengerjaan artikel ini. Baik teman, dosen, kakak, dan yang lainnya. Artikel ini dapat dibuat karena adanya bantuan mereka. Semoga artikel ini dapat bermanfaaat untuk banyak pihak. 


\section{KESIMPULAN}

Berdasarkan hasil penelitian dapat disimpulkan beberapa hal. Pertama, Pendidikan karakter memiliki tiga fungsi utama. Pertama, fungsi pembentukan dan pengembangan potensi. Pendidikan karakter membentuk dan mengembangkan potensi siswa agar berpikiran baik, berhati baik, dan berperilaku sesuai dengan falsafah pancasila. Kedua, fungsi perbaikan dan penguatan. Pendidikan karakter memperbaiki dan memperkuat peran keluarga, satuan pendidikan, masyarakat, dan pemerintah untuk ikut berpartisipasi dan bertanggung jawab dalam pengembangan potensi warga negara dan pembangunan bangsa menuju bangsa yang maju, mandiri, dan sejahtera. Ketiga, fungsi penyaring.

Pendidikan karakter memilah budaya bangsa sendiri dan menyaring budaya bangsa lain yang tidak sesuai dengan nilai nilai budaya bangsa dan karakter bangsa yang bermartabat. Guru dalam megengbangkan materi pembelajaran harus mengananlisis materi pembelajaran yang disesuaikan dengan masing masing nilai karakter. Tujuannya adalah antara materi pembelajaran dengan output yang dihasilkan sesuai dengan kebutuhan di masyarakat. Kedua, Pembelajaran daring, atau dalam jaringan, adalah terjemahan dari istilah online yang bermakna tersambung ke dalam jaringan komputer. Dengan kata lain merupakan pembelajaran tanpa tatap muka secara langsung antara guru dan siswa, tetapi dilakukan melalui jaringan internet (online) dari tempat yang berbeda-beda. Ketiga, Prinsip strategi Multiple Intelligences pada pendidikan karakter masih menggunakan prinsip pendekatan pembelajaran konstruktivistik. Peserta didik secara aktif mengembangan kedelapan potensi yang dimiliki disesuaikan dengan kompetensi dasar yang diajarkan dan bagaimana aktualisasinya terutama jika ada kaitan dalam menghadapi Covid-19.

Strategi implementasi pendidikan karakter melalui multiple intelligences berbasis portofolio dengan diintegrasikan pada mata pelajaran merupakan suatu upaya dalam proses pembelajaran untuk dapat mengembangkan life skill atau kecakapan peserta didik. Berdasarkan simpulan tersebut dapat dikemukakan saran yaitu, pertama, guru harus diberikan pemahaman bagaimana teknik dan strategi dalam pendidikan karakter pada pembelajaran daring yang merupakan pengejawantahan belajar dari rumah. Guru harus berusaha kreatif dalam menggali informasi dan karakteristik peserta didik dalam menentukan model-model pembelajaran dengan hasil belajar yang diharapkan pada pembelajaran daring. Keberhasilan pendidikan karakter bangsa pada masa Covid-19 membutuhkan peran utama orang tua siswa dan lingkungan rumah sebagai mitra sekolah dalam usaha Nation and Character Building.

\section{REFERENSI}

Akin, Terri, dkk. 1995. Character Education in Americaes School. California: Innerchoice Publishing. Alawiyah, F. (2012). Kebijakan dan Pengembangan Pembangunan Karakter Melalui Pendidikan Di Indonesia. Sekretariat Jenderal DPR-RI. 
Implementasi Nilai-Nilai Kewarganegaraan Terhadap Pembelajaran Daring, Jessica Angeline De Eloisa Tobing, Dinie Anggraeni Dewi

Andrianti. S. (2019). Pendekatan Model Pembelajaran Berbasis Portofolio dalam Meningkatkan Tanggung Jawab Belajar Mahasiswa di Sekolah Tinggi Teologi. Jurnal Teologi dan Pendidikan Kristiani .3, (2). 2541-3945 (online). http://www.sttintheos.ac.id/ejournal/index.php/dunamis Anggraini, L. Pendidikan di sekolah dasar dalam rangka menyongsong kenormalan baru. Webinar Nasional. Program Studi Pendidikan Sekolah Dasar. Universitas Dwijendra, Juni 2020. Denpasar. Surat Edaran Nomor 4 Tahun 2020 Tentang Pelaksanaan Kebijakan Pendidikan Dalam Masa Darurat Penyebaran COVID-19.

Undang-Undang Republik Indonesia Nomor 20 Tahun 2003 Tentang Sistem Pendidikan Nasional. Yuliana, 2020. Coronavirus diseases (Covid-19). Fakultas Kedokteran Universitas Lampung.Tesis, 